\title{
EXPLORING THE VOICES OF INDONESIAN NON-NATIVE ENGLISH-SPEAKING TEACHERS TEACHING ABROAD
}

\author{
Ancila Putri Perwitasari ${ }^{1}$, Hanna Sundari ${ }^{2}$ \\ ${ }^{1,2}$ Pendidikan Bahasa Inggris, Fakultas Pascasarjana, Universitas Indraprasta PGRI \\ Iciladyah@gmail.com, ${ }^{2}$ hanna.sundari@gmail.com
}

\begin{abstract}
Abstrak
Penelitian ini bertujuan untuk mengetahui dan mengali pengalaman dan praktik mengajar para guru Indonesia yang mengajar bahasa Inggris dan bagaimana mereka melihat diri sebagai nonNEST yang mengajar di wilayah timur laut Thailand. Dipandu oleh pendekatan kualitatif desain penelitian interview dari Kvale (2007), enam orang guru Indonesia yang mengajar di timur laut Thailand diundang dan ikut serta dalam 2 fase wawancara. Temuan penelitian menunjukkan bahwa guru Indonesia mengajar di Thailand didorong oleh berbagai alasan, diantaranya peningkatan pengalaman mengajar, memperoleh pengakuan, dan mendapatkan penghasilan lebih baik. Selama mengajar di sekolah SD maupun SMP/SMA di timur laut Thailand, para guru mengaku memperoleh pahit manis pengalaman hidup dan mengajar. Hambatan bahasa menjadi masalah utama karena guru dari Indonesia dan siswa Thailand berbicara bahasa yang berbeda. Ketiadaan sumber belajar dan faktor siswa juga menjadi tantangan berikutnya. Penerapan beragam strategi mengajar dan penyesuaian pada tingkat bahasa siswa merupakan solusi realistik untuk menjaga profesionalitas mengajar. Lebih lanjut, para guru juga mengakui bahwa siswa dan guru Thailand menyambut mereka dengan baik dan mereka merasa diterima. Para guru juga menyebut bahwa kehadiran mereka untuk mengajar bahasa Inggris di Thailand menandakan bahwa guru Indonesia memiliki kualifikasi internasional.
\end{abstract}

Kata Kunci: Non-NEST; Guru Bahasa Inggris; Pengajaran Bahasa Inggris; Penelitian Interview

\begin{abstract}
The purpose of this research was to explore the teaching experience and practices of Indonesian teachers who teach English and how they see themselves as NNESTs teaching in northeastern Thailand. Guided by the qualitative approach of interview research inquiry by Kvale (2007), six Indonesian teachers who teach English in northeastern Thailand were invited and took part in two phases of interview sessions. The findings show that to teach English in Thailand, Indonesian teachers were driven by various internal motivations, including expanding teaching experience, receiving recognition, and getting higher salary. During their job assignment as English teachers at primary/secondary in several districts in the northeastern region, they have encountered bittersweet life and teaching experiences. The language barrier is one of the prominent problems since Indonesian teachers and Thai students speak different languages. Moreover, the unavailability of teaching sources and student factors have become the next challenge to cope. Application of various teaching strategies and adjustment to student levels can be a realistic solution to maintain professional teaching service. Furthermore, they also admitted that Thai students and other Thai teachers are welcomed, and they felt positive acceptance. They also mentioned that their presence as Indonesian non-NESTs teaching English in Thailand indicates that Indonesian teachers have international qualification to be English teachers at international level.
\end{abstract}

Keywords: Non-NEST; EFL Teacher; Teaching English; Interview Study

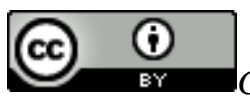




\section{INTRODUCTION}

One of the consequences of English as an international language is that non-native English speakers outnumber native speakers of English. As a result, the demand for English language teachers around the world has rapidly increased over the years, and nonnative English-speaking teachers (non-NESTs) fill the need of teachers, specifically in countries whose status of English is as a foreign language. English language teaching in Thailand has become one of the favorite jobs for native and non-native English teachers. Many of them try their luck to work in Thailand. Moreover, lots of English teachers' agencies in Thailand provide jobs and teachers training for non-Thai people to work in Thai private and public schools. Thai education institutions realize that most English teaching models in Thailand are still teacher learning-centered that makes the students passive to learn English. To address this issue, Thai education brings foreign English teachers to improve English language education in its country and the teaching competencies of Thai English teachers as well.

The pride of being one of the ASEAN countries that have never been colonized and the use of Thai as an official language may influence the way of thinking for Thai people, including Thai students in learning English. Thonginkam (2003: 19) points out that, "There are no other needs for students at all why students should strive to have contact with or master English. They can survive or even live perfectly happily without English". English has become the most prestigious foreign language since the reign of King Rama V (1868-1910); the greater need for English increases because many foreigners visited Thailand (Darasawang, Reinders, \& Waters, 2015). To date, English is used as a foreign language and plays an essential role in education and business in Thailand. Even though English has been a foreign language in Thailand that students must study in schools, Thai's English proficiency is still low compared to its ASEAN neighbor countries like the Philippines, Malaysia, and Singapore. It is supported by Education First (EF Education First, 2020) reported that Thais' English proficiency is in the category of very low proficiency, and Thailand is one of the lowest rank countries in Asia. Hence, to fulfill the need of English teachers with good competency and professionalism, native and non-native English teachers have been hired by most private, public schools, and universities around the country. Some non-native English teachers in Thailand are hired to help local English teachers in teaching English.

To acquire the teaching competency standards, Indonesian non-NESTs in Thailand need to pass some requirements such as passing the TOEIC score of 600, police background check, and health check. They also work under the supervision of the Thai Education Department in each province. Additionally, they have to follow the rules of being foreign teachers' standards from the Thai Education Department and Thai immigration. Each Thai school also has the rules and standards as teachers who depend on the school regulations. An example of the rules and standards is that all Indonesian EFL female teachers in North-Eastern have to wear a skirt, bun their hair, and wear Thai costumes for a special day or occasion. While for Indonesian EFL male teachers, they have to have tidy hair and wear long pants. The Indonesian non-NESTs also have to promote the ASEAN motto: One vision, one identity, one community. Therefore, the Indonesian NNESTs not only fulfill the teaching standard but also respect and follow Thai cultures.

The number of studies that dealt with the practices, perception and the policy of non-NESTs around the world and Asian countries, such as Hungary (Árva \& Medgyes, 2000), China (Wang \& Fang, 2020), Korea (Ahn, 2020; Chun, 2014), and Vietnam and 
Japan (Walkinshaw \& Oanh, 2014) has been extensively investigated among students and teachers. To be more specific, in Thailand, numerous research has been conducted in the issues of NEST and non-NEST. For instance, Todd and Pojanapunya (2009) explored the implicit attitudes of Thai students towards native and non-native English speaking teachers. Moreover, Grubbs, Jantarach, and Kettem (2010) examined how students in foundation English classes perceive their Thai and native-speaking teachers. Then, in 2019, Ulla (2019) found that Filipino teachers encountered some personal and professional issues, including those which stemmed from their status as so-called 'nonnative speaker teachers' (NNEST) of English when teaching English in Bangkok, Thailand.

However, to our knowledge, the challenges and experiences of Indonesian nonNESTs who teach in other countries, particularly in Thailand, remain under study. Their experiences and perceptions of being non-NESTs among native Thais in northeastern Thailand are still little known and worth studying. Therefore, this present research reports an interview study of Indonesian non-NESTs who had taught or currently teach in Thailand regarding their experiences, challenges, opportunities, teaching strategies, and perceptions. Therefore, this present research was guided by the following research questions (1) How do the Indonesian non-NESTs experience teaching English in Northeastern Thailand, including teaching practices/strategies and challenges? (2) How do they perceive themselves as Indonesian non-NESTs (non-native English and non-native Thais) who teach English in North-eastern Thailand?

\section{RESEARCH METHOD}

In this study, the researchers applied an interview study as a method for qualitative research design to guide the overall research procedure. Walliman (2011) states that qualitative research is used to get information on people's actions and to hold by asking them to give an interpretation of their experience. Meanwhile, the interview study is used to gather information from the interviewee's experiences, views, and beliefs regarding a specific question (Lambert \& Loiselle, 2008) to obtain descriptions of the interviewee's lived world with respect to interpretation of the meaning of the described phenomenon (Kvale, 2007). This qualitative interview research seeks to understand the teaching practices, including the strategy and challenge of Indonesian teachers who teach English and how they see themselves as non-NESTs teaching in North-eastern Thailand through interview. Guided by stages of an interview inquiry as proposed by Kvale (2007), the research procedure included thematizing/formulating the purpose, designing research plan, interviewing based on the interview guide, transcribing interview material from oral speech into written text, analyzing the collected data, verifying the interview findings, and reporting it.

\section{Participants}

The subject of the study was Indonesian non-NESTs who had experienced in teaching English abroad. We preferred the research participants of Indonesian NNESTs who had taught or are teaching English at formal schools in North-Eastern Thailand. As stated by Creswell (2012), in selecting participants, the researchers intentionally selected individuals and sites to learn or understand the central phenomenon, in this case, the experiences of being a non-NEST teaching English abroad. To achieve the research purpose, we selected Indonesian non-NEST who teach in North-Eastern Thailand. Since the first researcher has experience teaching English in Thailand years ago, some of the 
Indonesian non-NESTs fulfilled the criteria of the participants were invited. They were contacted and asked for consent and permission to participate in this study.

Table 1 Demographic information of participants

\begin{tabular}{|c|c|c|c|c|c|}
\hline $\begin{array}{c}\text { Teacher- } \\
\text { participants }\end{array}$ & Sex & $\begin{array}{l}\text { Educational } \\
\text { Background }\end{array}$ & $\begin{array}{l}\text { Teaching } \\
\text { Experience } \\
\text { (In general) }\end{array}$ & $\begin{array}{l}\text { Teaching } \\
\text { Experience in } \\
\text { North-eastern } \\
\text { Thailand }\end{array}$ & $\begin{array}{l}\text { School Level of } \\
\text { teaching in North- } \\
\text { eastern Thailand }\end{array}$ \\
\hline 1 & $\mathrm{~F}$ & $\begin{array}{c}\text { Bachelor's } \\
\text { degree }\end{array}$ & 4 years & 1 year 7 months & Secondary \\
\hline 2 & $\mathrm{~F}$ & $\begin{array}{l}\text { Bachelor's } \\
\text { degree }\end{array}$ & 6 years & 1 year & Primary \\
\hline 3 & $\mathrm{~F}$ & $\begin{array}{l}\text { Bachelor's } \\
\text { degree }\end{array}$ & 6 years & 1 year & Primary \\
\hline 4 & M & $\begin{array}{l}\text { Bachelor's } \\
\text { degree }\end{array}$ & 2 years & 2 years & Primary \\
\hline 5 & $\mathrm{~F}$ & $\begin{array}{c}\text { Master's } \\
\text { degree }\end{array}$ & 9 years & 2 years & Secondary \\
\hline 6 & $\mathrm{~F}$ & $\begin{array}{l}\text { Bachelor's } \\
\text { degree }\end{array}$ & 6 years & 1 year 7 months & Primary \\
\hline
\end{tabular}

Having been informed by the research questions and procedure, six Indonesian non-NESTs were willing to take part in the interview sessions. All participants graduated from several universities in Indonesia, majoring in English education. The details of demographical information about the teacher-participants can be seen in Table 1 .

All teacher-participants have experienced or are still teaching in primary and secondary schools in several districts in North-eastern Thailand. Located on the Khorat Plateau in the northeastern region of Thailand, North-eastern Thailand, also called Isan/Isaan as the largest region in the country, consists of 20 provinces and a home of many tribal/local languages. Districts in this region have been recognized as the most underdeveloped in the country in which average education achievement ranges from around 6 to 9 years (Ngampornchai \& Adams, 2016).

\section{Instrumentation}

Online interview sessions were conducted twice in two phases. At first, four participants were interviewed to capture their experiences and teaching practices as the non-NESTs in Thailand. The second interview involved two other teacher-participants (six teachers in total) in exploring the motives, the teaching challenges and how they perceived themselves as Indonesian teachers who teach English in Thailand.

The interview study in this research used semi-structured interview because it is a flexible approach to the interview process. Besides, the focus is on permitting the interviewees to tell their stories rather than answer a series of questions. A set of guided open-ended questions has been prepared before the interview sessions ( 3 questions at interview 1 and 7 questions at interview 2). Since all the teacher-participants stayed in various places in North-Eastern Thailand when the data were gathered, the interviews 
were then conducted online via electronic mail and voice note of messenger application. Only one session was through a face-to-face interview with the teacher-participant's (P2) agreement. From the two phases of interview, they were in English and took around 7 hours in total.

\section{Data Analysis}

The gathered data from interviews were then transcribed from audio to verbatim for further analysis. Qualitative content analysis was selected in analyzing the gathered data. The researchers read, reread, and analyzed the data in separate places and time. We focused on the text content to answer the proposed research questions. For any different findings, we did intensive discussions to get final decisions.

\section{Trustworthiness}

To warrant the trustworthiness and rigor of the research, we considered the consistency of the data and the confirmability of the findings. We checked the consistency of the participants' responses among the two interviews. Moreover, to triangulate data and confirm the findings, we distributed a set of closed-ended questions to the participants and examined their consistency. We found that the participants' responses to the questions from interviews and the response to the findings were consistent and confirmed.

\section{RESULT AND DISCUSSION}

This interview inquiry seeks to obtain the experience of Indonesian teachers who teach English in Northeastern Thailand. Moreover, this current study also emphasized on the teaching strategy, challenges, and the teacher-participants' views of Indonesian nonNEST teaching abroad. The findings of the research were displayed to answer the proposed research questions.

\section{How do the Indonesian non-NESTs experience teaching English in northeastern Thailand, including teaching practices/strategies and challenges?}

As Indonesian non-NESTs who teach English in North-eastern Thailand, the teacher-participants expressed that, at first, they intentionally and purposefully joined the selection program or job vacation offered to them at their campus or from colleagues to teach English in Thailand, as on the interview excerpt below.

I got information from my lecturer in university that there was a teacher job vacancy in Thailand. So, I applied for that position. (IV2_Q1_P2)

I got some information from my lecturer at university. Then, I got a job interview. (IV2_Q1_P3)

Applying a job from a job vacancy by my major. (IV2_Q1_P5)

Besides getting a job as a teacher, the teacher-participants revealed that teaching English abroad or outside the home country offers advantages and added value for them. Their purposes go beyond working or teaching, and they stated that having teaching experience, getting high salary, and traveling abroad motivate them to take part in the program, as in the excerpt.

I wanted to expand my knowledge, skills, and experience in teaching and how to survive in another place other than Yogyakarta. It led me to enjoy the process of engaging with other people from another country and to learn how to deal with those who are also not familiar with English in daily life. (IV2_Q2_P2) 
I felt like it was cool, and I knew (from the previous Indonesia teacher at Phayak) that the salary and the environment were pretty cozy. (IV2_Q2_P4)

Nonetheless, one teacher-participant revealed that salary and savings became the main reason for getting this job. P6 stated that "Basically, my motivation to teach in Thailand is to get a salary with a small daily expense, so I can save more" (IN2_Q7_P6).

Concerning to first time teaching experience in northeastern districts in Thailand, four participants stated that none of them took special teaching program or teaching preparation before teaching abroad (IV1_Q3). However, most teacher-participants expressed their confidence in teaching since, prior to teaching in Thailand, they have taught English at schools in Indonesia.

At first, I felt confident enough since I had teaching experiences for years, both young learners and adult. (IV1_Q2_P1)

I was confident because I thought that I have the knowledge to share with the students and Thai people. (IV1_Q2_P2)

Personally speaking, I was confident because I've experienced teaching both primary and secondary for 4 years. (IV1_Q2-P4)

Though teacher-participants felt high confidence in teaching English at schools in North-eastern districts in Thailand, they admitted that feeling of confidence was not sufficient to achieve the working goals and teaching objectives. After having experienced teaching English for some time, they concluded that teaching English in Thailand was troublesome as well as challenging at the same time. The excerpts below describe the teacher-participants' responses on the difficulty of teaching English in Northeastern Thailand.

It was quite difficult due to the language barrier. Most students can't speak English fluently. Some of the students always think that English is hard. Besides, it's quite hard to be handled because there are too many students in one class. (IV2_Q1_P4)

It was difficult because I have not known the place, the school, yet the Thai students. Besides, it was my very first experience to teach abroad. (IV2_Q1_P2)

Being a stranger for the kids and couldn't speak their language was the real problem. (IV2_Q5_P1)

The teacher-participants mentioned some points to be considered as difficult factors to teach English in Thailand. They stated that they faced language/communication barriers, problems of class size, and experiencing culture shock.

In terms of the feeling of difficulty related to teaching English, the study finds out that the majority of Indonesian non-NESTs felt confident in teaching English, but they found some difficulty at first such as culture shock and language barrier. The findings are almost similar to the previous study conducted by Ulla (2019) that non-native EFL teachers face culture shock and cultural disagreement (Bailey, 2013), language barriers (Abramova, 2013), and dissatisfaction from people in the school (Fimyar, 2018). The participants experience culture shock because the environment is different from what they used to get in their home country, and it has a different culture to Indonesia. Besides, the language barrier occurs probably because Thai students mostly prefer to speak their mother language and they do not understand what Indonesian teacher-participants saying in English. On the other hand, Indonesian teacher-participants are not able to speak sufficient Thai language. However, as time goes by, to facilitate the Thai students, some Indonesian teacher-participants admitted that they learn the Thai language by themselves so that they can communicate and understand the students. 
Moreover, students' English proficiency and learning motivation also contributed to enhancing the teaching challenges, as teacher-participants reported below.

The challenge was that they are not really fluent in English. (IV2_Q3_P2)

It's difficult to change the students' habit to speak in English, they prefer to speak in Thai. (IV2_Q5_P4).

Difficulties explaining the materials to students because most students have limited English skills so that they can't understand the materials easily. (IV2_Q5_P5).

Even if I speak the simplest English, many of Thai students would not understand. (IV2_Q5_P6).

Regarding the challenges faced by the teacher-participants, most of them handled face various challenges, but almost similar to one another. All of them find out the same challenges that the students are lack practice and students are lack of discipline and motivation. The students are lack of practice is a big challenge for Indonesian non-NESTs to encourage Thai students to practice English. The students only practice and learn English in English time in the class. It is hard to deal with the students. Besides, students are lack discipline and motivation. The issue is because of the great influence of students' mother tongue happens in English class so that the students prefer to use the Thai language rather than English. Another issue is the pride of the Thai people since the fact that their country has never been colonialized by other countries leads the students to think that English is not important for them. Other challenges such as students are lack of interest in learning English was probably due to their way of thinking that English is difficult for them. Then, students are lack concentration in the class. It is influenced by the number of students in one class; commonly, a class had forty students. It is a less conducive environment for them to learn because of much noise in the class. Another challenge is the difficulty in finding material, resources, and time. Not all Thai schools provide enough material and resources for teachers. Mainly for teacher-participants who work in Maha Sarakham province far from the city. Consequently, they need to work hard to find and arrange teaching material.

The teacher-participants also uttered that finding appropriate teaching sources was one of the biggest challenges since its unavailability in schools in the district area.

For me, it was difficult. It was difficult since the learning sources (books, internet) were limited and difficult to find. Besides, only a few teachers could speak English. (IV2_Q1_P1) It's difficult to find any resources (books) written in the alphabet.... (IV2_Q5_P4)

Another challenge is the difficulty in finding material and resources for teaching. Not all Thai schools provide enough material and resources for English teachers. Mainly for Indonesian teachers who work in a province far from the city. Consequently, they need to work hard to find and arrange teaching material by themselves.

Having been surrounded by typical social-linguistic teaching/learning situations that did not fully support teaching English, teacher-participants, as non-NESTs in Northeastern Thailand, described several teaching strategies and practices to overcome the challenges they faced. One of the teacher-participants (P4) announced that "... so I need to go to a bookstore in the next town" (IV2_Q5_P4). They also mentioned some teaching strategies, such as providing attractive teaching media, selecting engaging teaching techniques during the sessions such as games and fun learning, as in the excerpt below. 
I used flashcards, games, songs, videos, and pictures. But I always vary my strategies depending on the students' levels, IEP and regular class. If I could say the students here are a special case because the strategy could not be used for all classes. (IV2_Q6_P1)

I tried to be a fun teacher by playing guitar, playing games in my classes, making videos, and interacting with them after the classes. (IV2_Q6_P4)

Moreover, the teacher-participants mentioned that "I used teaching media to help students understand better" (IV2_Q6_P4); one of them was by playing games as uttered by P4 "Sometimes I just used games to help me make the students more engaged in the learning process." (IV2_Q6_P4) and assigning quiz (IV2_Q6_P2). These teaching practices were to enhance students' learning motivation and engagement. One teacherparticipant (P3) narrated that applying full English during the English session can be an alternative solution to foster Thai students speaking English, as in the excerpt below.

I would not answer my students if they speak in Thai until at least they speak to me in English, even a little. (IV2_Q6_P3)

The majorities of participants use games and dialogue in their classes. The use of games is effective in teaching English. It is also in line with Constatinescu (2012 as cited in Gozcu \& Caganaga, 2016), who states some advantages of games in EFL, such as games increase students' motivation and desire for self-improvement. Games are easy to understand and use in class. They do not take a long time to be applied in class. The teachers can adjust the game as suitable as their purposes in teaching English. Also, the students are happy about playing games while learning English. The next technique is a dialogue that is used by all the participants. The dialogue is chosen to encourage the students to speak English. The simple dialogue usually is applied in the class such as asking about students' condition, their feeling, and activities. Other teaching strategies that are used are reading aloud, warming up, and brainstorming. The reading aloud, warming up, and brainstorming is chosen to involve the students in the learning process and encourage them to be more active in English class.

Regarding the language and communication barrier to both students and other Thai teachers at school that the Indonesian teacher-participants have encountered, they admitted learning the Thai language, specifically some Thai words and expressions (IV2_Q6_P6), and going out with other teachers and workers (IV2_Q6_P3) to interact and make communication in English-Thai. Here is the excerpt on how Indonesian teacherparticipants narrated how different languages among teachers and students became barriers in teaching Math in English among Indonesian teacher and Thai students.

Honestly, I taught Math in English at that time. It was very challenging yet enjoyable. I enjoyed the process of delivering my materials for them in English. The challenge was that they are not really fluent in English. At that time, I always shared with some students who understood English well to help me translate some of the terms in Thai. So, I also learned a bit of Thai language to help me explain the Math term for the students. And fortunately, it sometimes worked. However, I also sometimes felt that I failed to be a teacher because I couldn't make them understand what I was teaching. But then, I realized that because of the language barrier that we both had, we should work harder. (IN2_Q3_P2)

Another teacher-participant expressed that setting teaching goals to meet the students' level of proficiency was one of teaching solutions. The excerpt can be seen below. 
It is more challenging living a life in Thailand than teaching Thai students for me. Thai students and teachers are really friendly and nice. I don't expect much from the students after I observe their English skills. So, I set the teaching goals based on their proficiency. (IN2_Q3_P6).

Adjustment and adaptation to new teaching situations are some realistic solutions to maintain professional teaching service. At the same time, the teaching experience and repertoire can extensively be upgraded from time to time, from one teaching situation to another, as what the teacher-participants said in the interview on the excerpt below.

I thought I would be teaching in Bangkok, but unfortunately, I was in the borderline of Northeast Thailand. But in the end, I liked my district. But I really learned a lot on how to survive in another country. I have none but friends there. I really loved to have this experience. I thought it would be easier to teach foreign students in English, but it's never been there. Language barrier matters and patience is needed. (IN2_Q7_P2)

after 2 years teaching there, I've improved my teaching skills, known Thai educational system and culture. (IN2_Q7_P5)

\section{How do they perceive themselves as Indonesian non-NESTs (non-native English and non-native Thais) who teach English in northeastern Thailand?}

After having experienced teaching English among Thai primary and secondary students, some teacher-participants expressed that it was such as self-testing and proving and a great opportunity. Here is the excerpt on their perceptions of being Indonesian teachers who teach abroad.

I think it's a great opportunity for us to go further than we can. Because for me the challenges will motivate me more to find ways on how to teach them with those limitations. (IN2_Q4_P2)

I can also test myself whether I am ready for being an EFL teacher or not. (IN2_Q4_P1)

One teacher-participant revealed that the subject delivered by foreign teachers was less important, as in commenting "they thought the other teacher's subjects are more important than the lesson given by foreign teachers" (IV2_Q5_P2). However, other teacher-participants found positive acceptance among Thai students, teachers, and parents. The following excerpt shows the comments.

I didn't experience any circumstances where the parents or the school complained about my skills. (IN2_Q4_P4)

It is more challenging living a life in Thailand than teaching Thai students for me. Thai students and teachers are really friendly and nice. (IN2_Q3_P6)

Concerning the status of foreign teachers (non-NESTs), some teacher-participants stated that different nationalities could not be a central issue. Due to the fact that the demand for Indonesian teachers to teach English in Thailand is relatively high every year, it can be assumed that Indonesian teachers are welcomed and receive positive acceptance among Thai school communities in northeastern Thailand. Some teacher-participants revealed that their presence as Indonesian teachers who teach English in Thailand brought a positive image about the Indonesian teacher as an individual and Indonesia as a country. The following are the excerpt of their comments.

In my opinion, it doesn't matter what nationalities of the teachers. Both learning and teaching language matters are how the individual (teacher) delivers English without stopping learning the English itself. (IN2_Q4_P3) 
Just prove that we have the skills which are acquired to be an English teacher. We can prove it with our diploma, TOEFL or other tests, and the actual skills that we have (speaking, writing, reading, listening, and teaching). (IN2_Q4_P4)

That's kind of special because Indonesian (teacher) nationality can teach English in another country. It means that Indonesia (country) can compete with other countries and people from other countries also recognize that Indonesian are qualified to teach English in not only in Indonesia but also in other countries. (IN2_Q4_P5)

Indonesian teacher-participants perceived that teaching quality and professionalism at school define and determine who they are, more than nationality or home country. Then they saw that, as Indonesian citizens who teach English abroad, it indicated that Indonesian teachers have all the teaching qualities and meet the requirements to be professional English teachers at international levels.

\section{CONCLUSION}

This interview research aims at obtaining the descriptions of the teaching practices, including the strategy and challenge of Indonesian teachers who teach English and how they see themselves as non-NESTs teaching in northeastern Thailand. Driven by various internal motivations, including expanding teaching experience, receiving recognition, and getting higher salary, Indonesian teachers have undergone bittersweet teaching situations. During their job assignment as English teachers at primary/secondary in several districts in the northeastern region, Indonesian non-NESTs have faced some struggles. Language and communication are the prominent barriers since teachers and students speak different languages. Then to solve this problem, some Indonesian teachers try to learn the Thai language. Moreover, unavailability of teaching sources and student factors such as low motivation and proficiency have become the next challenge. Application of various teaching strategies and adjustment to student levels can be a realistic solution to maintain professional teaching service.

Furthermore, despite the difficulty in teaching situations, Indonesian teachers who teach English in northeastern Thailand admitted that Thai students and other Thai teachers are welcomed, and they felt positive acceptance. They also mentioned that their presence as Indonesian non-NESTs teaching English in Thailand indicates that Indonesian teachers have international qualifications to be English teachers at the international level.

This current interview study has limitations in several aspects. The limited invited teacher-participants in this research may lead to specific local information of how the Indonesian teachers experienced being non-NEST teachers abroad. Therefore, the generalization of the findings in another context should be wise and subtle. Moreover, the use of interview as a single instrument may not sufficiently describe the real teaching practices on site. It is highly advisable, hence, for future research to use other instruments such as observation to get better understanding of the phenomenon.

\section{REFERENCES}

Abramova, I. (2013). Grappling with language barriers: Implications for the professional development of immigrant teachers. Multicultural Perspectives, 15(3), 152-157. https://doi.org/10.1080/15210960.2013.809305

Ahn, S. (2020). Non-native english-speaking teachers in Korean english classrooms: Reflections through critical performative pedagogy. Reflective Practice, 21(1), 68-80. https://doi.org/10.1080/14623943.2019.1708713 
Árva, V., \& Medgyes, P. (2000). Native and non-native teachers in the classroom. System, 28(3), 355-372. https://doi.org/10.1016/S0346-251X(00)00017-8

Chun, S. Y. (2014). EFL learners' beliefs about native and non-native English-speaking teachers: Perceived strengths, weaknesses, and preferences. Journal of Multilingual and Multicultural Development, 35(6), 563-579. https://doi.org/10.1080/01434632.2014.889141

Darasawang, P., Reinders, H., \& Waters, A. (2015). Innovation in language teaching: The thai context. In P. Darasawang \& H. Reinders (Eds.), New Language Learning \& Teaching Environment: Innovation in Language Learning and Teaching the Case of Thailand (pp. 1-14).

EF Education First. (2020). EF english proficiency index. In Education First. Retrieved from https://www.ef.com.ec/epi/

Fimyar, O. (2018). "We Have a Window Seat": A Bakhtinian Analysis of International Teachers' Identity in Nazarbayev Intellectual Schools in Kazakhstan. European Education, 50(4), 301-319. https://doi.org/10.1080/10564934.2017.1344861

Gozcu, E., \& Caganaga, C. K. (2016). The importance of using games in EFL classrooms. Cypriot Journal of Educational Sciences, 11(3), 126. https://doi.org/10.18844/cjes.v11i3.625

Grubbs, S. J., Jantarach, V., \& Kettem, S. (2010). Teachers and teaching: Theory and practice Studying English with Thai and native - speaking teachers. Teacher and Teaching: Theory and Practice, 16(5), 559-576.

Kvale, S. (2007). Doing interviews. In Practical Research Methods in Education. https://doi.org/10.4324/9781351188395-2

Lambert, S. D., \& Loiselle, C. G. (2008). Combining individual interviews and focus groups to enhance data richness. Journal of Advanced Nursing, 62(2), 228-237. https://doi.org/10.1111/j.1365-2648.2007.04559.x

Ngampornchai, A., \& Adams, J. (2016). Students' acceptance and readiness for Elearning in Northeastern Thailand. International Journal of Educational Technology in Higher Education, 13(1). https://doi.org/10.1186/s41239-0160034-x

Thonginkam, A. N. (2003). Failure of the English Language education in Thailand. Galaxy, 6-15.

Ulla, M. B. (2019). Filipinos as EFL Teachers in Bangkok, Thailand: Implications for Language Education Policy in the ASEAN Region. RELC Journal. https://doi.org/10.1177/0033688219879775

Walkinshaw, I., \& Oanh, D. H. (2014). Native and non-native English language teachers: Student perceptions in Vietnam and Japan. SAGE Open, 4(2). https://doi.org/10.1177/2158244014534451

Walliman, N. (2011). Research Methods: The Basics. Oxon: Routledge.

Wang, L., \& Fang, F. (2020). Native-speakerism policy in English language teaching revisited: Chinese university teachers' and students' attitudes towards native and non-native English-speaking teachers. Cogent Education, 7(1). https://doi.org/10.1080/2331186X.2020.1778374

Watson Todd, R., \& Pojanapunya, P. (2009). Implicit attitudes towards native and nonnative speaker teachers. System, 37(1), 23-33. https://doi.org/10.1016/j.system.2008.08.002 